\title{
THE EXClusion OF PROPERTY RIGHTS FROM THE CHARTER: CORRECTING THE HISTORICAL RECORD
}

\author{
DWIGHT NEWMAN* AND LORELLE BINNION**
}

Canada's Constitution has been described as an outlier among the liberal constitutions of the world because it lacks a property rights provision. The history of how property rights came to be excluded has received relatively limited consideration. This article seeks to correct the historical record by utilizing forms of analysis within legal scholarship.
La constitution canadienne a été décrite comme un cas particulier parmi les constitutions libérales de ce monde parce qu'elle ne contient pas de disposition sur le droit à la propriété. L 'historique sur la raison pour laquelle le droit à la propriété a été exclu n'a fait l'objet que d'une contrepartie relativement limitée. Cet article cherche à corriger la version historique au moyen de formes d'analyse dans le cadre d'une bourse en droit.

\section{TABLE OF CONTENTS}

I. INTRODUCTION . . . . . . . . . . . . . . . . . . . . . . . . . . . . . . . . 543

II. THE LEgAL-INTELleCtUAl ClimAte FOR PROPERTY

Rights LEAding Up to 1982 . . . . . . . . . . . . . . . . . . . . . . . . . . . . 546

III. Political Manoeuvres ANd Divided ViewPoints $\ldots \ldots \ldots \ldots \ldots . \ldots 50$

IV. Three Mistaken Assumptions IN THE

EXCLUSION OF PROPERTY RIGHTS . . . . . . . . . . . . . . . . . . . 558

V. Conclusions ............................... 563

\section{INTRODUCTION}

On property rights, Canada’s Constitution has rightly been described as "something of an outlier among the liberal constitutions of the world."1 While property rights clauses appear in virtually every written constitution amongst the world's liberal democracies, ${ }^{2}$ Canada's written Constitution contains no property rights provision. Canada's history on this point is even more peculiar, in so far as property rights provisions actually assumed a lesser role in

BA (Regina), JD (Saskatchewan), BCL, MPhil, DPhil (Oxford); Professor of Law \& Canada Research Chair in Indigenous Rights in Constitutional and International Law, University of Saskatchewan. This research was funded, in part, through the Canada Research Chairs program. We thank Roy Romanow, Doug Schmeiser, and John Whyte for each reading a complete draft of the article and generously offering comments that drew upon their experiences in the 1982 negotiations. An earlier draft of this article was presented in two pieces at the Canadian Property Rights Conference 2013 in Ottawa during September, and we thank those present for their comments, including Matt Bufton, Tom Flanagan, Randy Hillier, Peter Jaworski, and Scott Reid. We also thank Amy Gibson, Leif Jensen, Michelle Lang, Marty Moore, Ben Rakochy, and Ryan Pederson for comments on a draft version presented in a small workshop and a seminar at the University of Saskatchewan. BSc (McGill), JD candidate (Saskatchewan); Research Assistant to Professor Dwight Newman. Gregory S Alexander, The Global Debate over Constitutional Property: Lessons for American Takings Jurisprudence (Chicago: University of Chicago Press, 2006) at 41.

Ibid (stating that, "[r]elatively few constitutional democracies with written constitutions lack a property clause. ... Western written constitutions lacking a property clause are especially rare” at 41). For citations to over five dozen constitutions with property rights provisions, see also Jeremy Webber \& Kirsty Gover, "Proprietary constitutionalism” in Mark Tushnet, Thomas Fleiner \& Cheryl Saunders, eds, Routledge Handbook of Constitutional Law (London: Routledge, 2013) 361 at 364, nn 7-12. 
its later rights instruments than in its earlier ones. ${ }^{3}$ Property rights figure in the statutory Canadian Bill of Rights, ${ }^{4}$ adopted in 1960, but do not appear in the 1982 Canadian Charter of Rights and Freedoms ${ }^{5}$ — despite the fact that the latter instrument generally carries forward and builds upon the text of the Bill of Rights.

Some casual observers might feel initially inclined to attribute this state of affairs to Pierre Elliott Trudeau, whose imprint is visible across Canadian constitutional texts, and who they may assume to have simply chosen to leave property rights out in the context of a political philosophy that might be perceived as not including a role for strong property rights protections. However, the history is far more complicated in that Trudeau had actually long advocated for a bill of rights that included property rights, but property rights were removed from his texts. ${ }^{6}$ Admittedly, these removals were always with his acquiescence in light of the overall political calculations at stake, ${ }^{7}$ but the exclusion of property rights certainly did not arise from any outright unwillingness on the part of Trudeau to include them.

Interestingly, the complicated history of how property rights came to be excluded from the Charter has received relatively limited serious consideration. Apart from one article by Alexander Alvaro in the Canadian Journal of Political Science ${ }^{8}$ and a few highly insightful pages by Gregory Alexander in his international comparative work on constitutionalized property rights, ${ }^{9}$ references to the exclusion of property rights in discussions of the history

Apart from the change between the Canadian Bill of Rights and the Charter of Rights, note that property-related rights shifted in some provincial human rights codes from a right to own or acquire property without discrimination to a simple prohibition on discrimination in relation to an opportunity to purchase. For example, in Saskatchewan, The Saskatchewan Bill of Rights Act, 1947, SS 1947, c 35, s 10 as repealed by The Saskatchewan Human Rights Code, SS 1979, c S-24.1, s 51, provided that "[e]very person and every class of person shall enjoy the right to acquire by purchase, to own in fee simple or otherwise, to lease, rent and to occupy any lands, messuages, tenements or hereditaments, corporeal or incorporeal, of every nature and description, and every estate or interest therein, whether legal or equitable, without discrimination because of the race, creed, religion, colour or ethnic or national origin of such person or class of persons." Now, The Saskatchewan Human Rights Code, ibid, s 10(1) simply says that "[n]o person shall, on the basis of a prohibited ground ... deny to any person or class of persons," or discriminate in any term of purchase, in relation to the chance to purchase a commercial unit or dwelling put up for sale or land or interest in land. The former actually contains a right to own, which the latter does not.

$4 \quad$ Canadian Bill of Rights, SC 1960, c 44, s 1(a) [Bill of Rights].

5 Canadian Charter of Rights and Freedoms, Part I of the Constitution Act, 1982, being Schedule B to the Canada Act 1982 (UK), c 11 [Charter].

$6 \quad$ Amongst other occasions, Trudeau proposed property rights clauses in 1969 (The Right Honourable Pierre Elliot Trudeau, The Constitution and the People of Canada: An Approach to the Objectives of Confederation, the Rights of the People and the Institutions of Government (Ottawa: Information Canada, 1969) at 52-53); in 1978 (Canada, The Constitutional Amendment Bill: Text and Explanatory Notes (June 1978) at 5 [Constitutional Amendment Bill]); in 1981 (House of Commons Debates, 32nd Parl, 1st Sess, vol 6 (27 January 1981) at 6595) (The Right Honourable Pierre Elliot Trudeau)). See also Library of Parliament, "Property Rights and the Constitution" by David Johansen (Ottawa: Parliamentary Research Branch, 1991).

$7 \quad$ Trudeau, of course, did not have complete control over how matters developed, but property rights were obviously rights without which he still accepted the Charter text, which would very likely not have been the case had, say, language rights been removed from the text. There is an argument that for Trudeau, both served related purposes. As put by Alexander, supra note 1 at 46 , "[t]he property clause initiative was essentially an effort to stitch all of Canada's provinces together in economic matters, as part of a broader effort to strengthen national unity." 
of constitutional patriation and of the Charter have tended to be minimalist ${ }^{10}$ — or even entirely absent. ${ }^{11}$ These statements remain true even in an era when there is a sudden surge of new writing on patriation. Some of this writing is from participants seeking to ensure dimensions of the patriation process that they recollect are recorded for posterity, and some consists simply of re-engagement with the historical record some decades on, but in neither case has there been additional attention to this particular aspect of the history. ${ }^{12}$

There have of course been arguments put against the exclusion of property rights in the context of later rounds of possible constitutional reform by the likes of Richard Bauman and Jean McBean. ${ }^{13}$ Thus, in 1988, McBean tried to analyze possible legal effects that might arise were property rights to be added to the Charter, as was being proposed at the time. ${ }^{14}$ In 1991 , Bauman reacted to discussion of the idea in the context of constitutional reform discussions by warning of potential legal confusion and interpretive difficulties that could arise as well as by warning of the risks of how courts might intervene in governmental policy. ${ }^{15}$ But neither seeks to engage in any lengthy explanation of how it was that property rights had been excluded in the first place. Similarly, Dwight Newman, writing recently concerning the possible use of the bilateral amending formula to achieve property rights clauses in particular provinces that are currently seeking them, contributes to a broader debate on property rights but does not examine the history of their exclusion in that article. ${ }^{16}$

Alvaro's leading account of the exclusion of property rights, ${ }^{17}$ written from a political science perspective, has much to contribute to an understanding of this history. However, the

See e.g. Robert Sheppard \& Michael Valpy, The National Deal: The Fight for a Canadian Constitution (Toronto: Fleet Books, 1982) (offering only very brief comments at 148, 151); Peter H Russell, Constitutional Odyssey: Can Canadians Become a Sovereign People?, 3rd ed (Toronto: University of Toronto Press, 2004) (offering only a one-sentence explanation at 115); Roy Romanow, John Whyte \& Howard Leeson, Canada ... Notwithstanding: The Making of the Constitution 1976-1982 (Toronto: Carswell/Methuen, 1984) (offering only brief references at 231, 237, 243); Sujit Choudhry, "The Lochner era and comparative constitutionalism” (2004) 2:1 Intl J Constitutional L 1 (offering repeated references to Lochner as a motivating factor in the drafting of section 7 and implicitly suggesting this affected the exclusion of property rights at 15-27).

11 They receive no mention in such other leading works as Ron Graham, The Last Act: Pierre Trudeau, the Gang of Eight, and the Fight for Canada (Toronto: Allen Lane Canada, 2011).

12 See e.g. Howard Leeson, The Patriation Minutes (Edmonton: Centre for Constitutional Studies, 2011) (publishing, for the first time, notes from a participant at the November 1981 meetings); Graham, ibid (re-engaging with the whole history in ways that put together previously unconnected information); Barry L Strayer, Canada's Constitutional Revolution (Edmonton: University of Alberta Press, 2013) (offering Justice Strayer's personal perspective on how matters unfolded); Frédéric Bastien, La Bataille de Londres: Dessous, secrets et coulisses du rapatriement constitutionnel (Montréal: Éditions Boréal, 2013) (discussing patriation from a sovereigntist perspective and, in doing so, uncovering significant new archival material on the actions of some Supreme Court of Canada justices during the process); Brian Peckford, Some Day the Sun Will Shine and Have Not Will Be No More (St John's: Flanker Press, 2012) (presenting an account differing from some others and printing some documents in the appendix. Some important material concerning patriation, however, will remain locked up for decades yet. For example, although Howard Leeson has published his version of minutes from the November 1981 meeting, Doug Schmeiser (who served as constitutional advisor to the Manitoba government) took extensive notes at a whole series of patriation-related meetings that he recently archived, but with a lengthy lock-up so as to ensure definitively that these notes do not emerge during the lifetimes of any participants: University of Saskatchewan Library, Archives and Special Collections, MG154, DA Shmeiser, Series 2 (closed until July 2031).

13 Jean McBean, "The Implications of Entrenching Property Rights in Section 7 of the Charter" (1988) 26:3 Alta L Rev 548; Richard W Bauman, "Living in a Material World: Property Rights in the Charter" (1993) 3:3 Const Forum Const 49.

McBean, ibid.

Bauman, supra note 15.

Dwight Newman, "The Bilateral Amending Formula as a Mechanism for the Entrenchment of Property Rights” (2013) 21 Const Forum 17 [Newman, "Bilateral Amending”]. Supra note 8 . 
fact that he approached the question from a political science perspective also limits the understanding of what occurred. In this article, we seek to correct the historical record on property rights, partly by bringing to bear some forms of analysis possible within legal scholarship. In doing so, we do not reject the role of political science in understanding constitutional history. Indeed, we will draw upon both political theory and a narrative of how different political forces interacted at the time of patriation. However, we do go on to argue that attention to the framing of actual legal texts has a significant contribution to make in highlighting how the negotiation process on constitutional patriation ended up excluding property rights from constitutional protection.

In Part II of this article, we situate the discussion that occurred in 1982 within a different legal-intellectual climate. The climate does not necessarily persist today but its circumstances set up matters for the exclusion of property rights in 1982. In Part III of this article, we provide an elaborated narrative of the exclusion of property rights and we show how, while situated within the legal-intellectual climate of the day, the exclusion resulted also from a combination of chance factors and perceptions about legal interpretations that might ensue. In Part IV of the article, we put those perceptions about legal interpretations to the test of legal analysis, and we argue that, even with limited legal analysis, it becomes possible to suggest that many of the presumptions about the effects of a property rights provision reflected certain legal misapprehensions, at least given how the rest of the constitutional text turned out.

In the concluding Part V, we argue that a corrected reading of the historical record on the exclusion of property rights suggests that their exclusion was based on a combination of historical chance factors and legal misapprehensions. One important result to which this article leads is that a corrected reading of the historical record may implicitly lend some support to present-day arguments for a property rights clause, albeit in the nuanced form of clearing the ground for those arguments by showing that the exclusion of property rights in 1982 should exert no particular hold over longer-term thinking on the issue. This article does not itself pursue the substantive arguments on a property rights clause but seeks to present a narrative of how they came to be excluded and why that contingent and time-bound choice as to their exclusion should not continue to control the debate.

\section{The Legal-Intellectual Climate FOR PROPERTY RIgHTS LEADING UP TO 1982}

The 1982 patriation did not take place via some revolutionary event, and the processes of constitutional negotiation were, in many respects, quite ordinary discussions, filled with human tendencies and human frailties. ${ }^{18}$ One of the implications of this statement is that the 1982 patriation did not occur outside of and externally to Canadian history or to the intellectual currents of the time but within the ideas of the time. 
This historicity of the Constitution is actually apparent in various elements of the final agreement, including sections within the Charter. Aside from those sections of the Charter that were always intended to craft a national narrative rather than to embody universal rights - and here we speak especially of such matters as the language rights provisions, ${ }^{19}$ as well as aspects of the mobility rights provision ${ }^{20}$ — even the rights provisions of the Charter bear the markings of their time. For example, the ultimate presence of the notwithstanding clause in section 33 has led to much spilt ink concerning its significance, ${ }^{21}$ but in one sense, it embodies quite simply the fact that, for at least significant parts of the country to that point in time, the Canadian governmental tradition was one of parliamentary sovereignty. ${ }^{22}$ If section 33 has been subject to more heavy critiques since, ${ }^{23}$ or if the conceptions of its proponents have shifted in certain ways, this fact means simply that its significance within an evolving history shifts with the times.

As a second example, one could mention the deliberate decision to preclude from judicial contemplation the possibility that affirmative action programs could violate equality rights. ${ }^{24}$ The inclusion of a provision like section $15(2)^{25}$ — since held to have almost the effect of simply exempting governmental programs that have ameliorative purposes from equality rights scrutiny ${ }^{26}$ — marked a decision not to allow the courts to follow the American route

Charter, supra note 5, ss 16-23. See also Guy Régimbald \& Dwight Newman, The Law of the Canadian Constitution, 1st ed (Toronto: LexisNexis, 2013) ("[a]lthough accounts of the Charter sometimes underemphasize the point, the Charter is also a constitutional instrument that constitutes Canada in fundamental ways related to Canadian identity. As a major part of this identity-constituting role, sections 16 through 23 of the Charter contain a set of detailed language rights specific to the circumstances of Canada" at 696).

$20 \quad$ Charter of Rights, ibid, s 6. See also Sujit Choudhry \& Richard Stacey, "Independent or Dependent? Constitutional Courts in Divided Societies”, in Colin Harvey \& Alex Schwartz, eds, Rights in Divided Societies (Oxford: Hart Publishing, 2012) 87 at 107.

21 For a balanced comment and reference to much of the literature, see Jeffrey Goldsworthy, Parliamentary Sovereignty: Contemporary Debates (Cambridge: Cambridge University Press, 2010) at 202-24. See also Tsvi Kahana, “Understanding the Notwithstanding Mechanism” (2002) 52:2 UTLJ 221; Tsvi Kahana, "The notwithstanding mechanism and public discussion: Lessons from the ignored practice of section 33 of the Charter" (2001) 44:3 Can Public Administration 255.

22 It is of note that "the provincial premiers articulating such a concern [about the shift of power away from democratic legislators] most strongly within discussions around the proposed Charter of Rights were Allan Blakeney and Peter Lougheed, who stood at opposite ends of the ideological spectrum on political issues but who shared a common vision of the place of democratic processes" (Régimbald \& Newman, supra note 19 at 570 ).

23 See e.g. John D Whyte, “On Not Standing for Notwithstanding” (1990) 28:2 Alta L Rev 347 (example of mounting academic criticism in years subsequent to Charter). Whyte called for the repeal of section 33, something advocated in the political arena by Liberal leader Paul Martin in the 2006 federal leaders debates ("2006 Leaders Debate (Highlights)” CBC Digital Archives, online: <www.cbc.ca/archives/ categories/politics/elections/leaders-debates-1968-2011-arguing-for-canada/leaders-debate-1968.html>) although he had also been the only federal leader ever to promise its use. When asked in December 2003 whether he would use the notwithstanding clause if the Supreme Court of Canada required churches to perform same-sex marriages, he said "Oh yes, I would. I would look at it if it was a question of affirming a [religious] right” "“Analysis \& Commentary: The Leaders, on the record" Canada Votes 2004, online: $<$ www.cbc.ca/ canadavotes2004/analysiscommentary/ontherecord.html>).

24 See Alberta (Minister of Aboriginal Affairs and Northern Development) v Cunningham, 2011 SCC 37, [2011] 2 SCR 670 [Cunningham] (stating that "[a]t the time the Charter was being drafted, affirmative action programs were being challenged in the United States as discriminatory - a phenomenon sometimes called reverse discrimination. The underlying rationale of s. 15(2) is that governments should be permitted to target subsets of disadvantaged people on the basis of personal characteristics, while excluding others" at para 41).

25 Charter of Rights, supra note 5, s 15(2): "Subsection (1) does not preclude any law, program or activity that has as its object the amelioration of conditions of disadvantaged individuals or groups."

26 See $R v$ Kapp, 2008 SCC 41, [2008] 2 SCR 483 at para 41. But see also Cunningham, supra note 24 at para 44 . 
of arguing over affirmative action programs. ${ }^{27}$ The idea was to ensure that what was seen as an important tool of governmental policy in advancing equality was not put at risk. ${ }^{28}$ The impact, however, could also be read as one of having embodied in the constitutional text the idea held at a particular time on the policy merits of affirmative action programs when, for example in the United States, the ideas of today on the policy effects and constitutionality of such programs are shifting rapidly. ${ }^{29}$

The omission of property rights is, on our argument, partly a third instantiation of this point. Alvaro's argument is consistent with this general claim in that he situates the exclusion of property rights within a grand historical narrative. ${ }^{30}$ However, he describes this narrative in terms of an alleged grand shift from so-called proprietarian systems, "grounded in the belief that the basic role of government is restricted to the preservation and protection of property," 31 to so-called "democratic-communitarian systems" that are "rooted in the representation of majority and community interests." ${ }^{32}$ His claim is that property rights were no longer within the realm of rights discourse in 1982 because of a concern that they limited the actions of governments: "as public debate grew concerning the need to stitch an entrenched bill of rights into Canada's constitutional fabric, there were renewed concerns about the permanence of Canada's democratic values. Unclear was the effect an entrenched bill of rights, with protection of property ownership, would have on those values.»33

Alvaro's description is not entirely wrong, and we will show in the next section that some of the political actors involved were in fact potentially acting out of a simple concern about property rights limiting their powers more than some other rights, even though that concern is ultimately inconsistent with some of what they did permit in the Constitution. ${ }^{34}$ However, it sets matters up in terms of starker alternatives than were actually at stake, and it overlooks simpler explanations available within the legal-intellectual culture of the time.

Part of the context in which discussions took place about the Charter was of course, as Alvaro acknowledges, ${ }^{35}$ one in which the spectre of the Lochner-era ${ }^{36}$ jurisprudence of the

The long line of American affirmative action cases stretches from Regents of the University of California v Bakke, 438 US 265 (1978) to Fisher v University of Texas at Austin, 133 S CT 2411 (2013) [Fisher]. See Cunningham, supra note 24 at para 41.

Self-professed liberals are writing such works as Richard H Sander \& Stuart Taylor, Jr, Mismatch: How Affirmative Action Hurts Students It's Intended to Help, and Why Universities Won't Admit It (New York: Basic Books, 2012), and polling data show support for affirmative action at a record low. See Domenico Montanaro, “NBC News/WSJ Poll: Affirmative action support at historic low,” NBC News (11 June 2013), online: <firstread.nbcnews.com/_news/2013/06/11/18885926-nbc-newswsj-pollaffirmative-action-support-at-historic-low $>$. In its recent decision in Fisher, supra note 27, the Supreme Court of the United States avoided making any major new determination, thus avoiding a major division in the Court.

Alvaro, supra note 8

Ibid at 310.

Ibid.

Ibid at 317.

For example, the premiers ultimately accepted the inclusion of Aboriginal rights in the Constitution even though constitutionalized Aboriginal rights certainly impact upon their exercise of jurisdiction over lands and natural resource. Obviously, factors other than simply the scope of impact on the provinces (such as perceived justice) were at play, but nonetheless the point remains interesting. For a discussion of some of the interplay of natural resource jurisdiction and Aboriginal rights, see generally Dwight Newman, Natural Resource Jurisdiction in Canada (Toronto: LexisNexis, 2013) [Newman, Natural Resource]. On the different types of property rights in different constitutions, including both private property rights and Aboriginal property rights, see also Webber \& Gover, supra note 2.

Alvaro, supra note 8 at 318.

Lochner v New York, 198 US 45 (1905). 
United States Supreme Court seemed to loom large. A number of the political actors involved feared the prospect of the courts carrying out "substantive due process" review in ways that limited democratic programs implementing a social welfare state, ${ }^{37}$ with such results as the endless parsing of the language of section 7 of the Charter, ${ }^{38}$ ultimately to no effect when the Supreme Court of Canada adopted a "living tree" analysis and found the meaning of section 7 to have changed from the originally intended meaning as quickly as two years after the Charter's enactment. ${ }^{39}$

However, it also bears noting that the dominant American intellectual discourse of the time had developed views of rights that fit with the maintenance of the New Deal and even the ongoing expansion of the social welfare state. John Rawls's widely influential A Theory of Justice, ${ }^{40}$ published in 1971, argued for the protection of a set of basic liberties that initially appeared to include economic freedom:

The basic liberties of citizens are, roughly speaking, political liberty (the right to vote and to be eligible for public office) together with freedom of speech and assembly; liberty of conscience and freedom of thought; freedom of the person along with the right to hold (personal) property; and freedom from arbitrary arrest and seizure as defined by the concept of the rule of law. ${ }^{41}$

However, this mere right did not include any protection of economic liberties, ${ }^{42}$ with economic circumstances instead subjected to the second, so-called “difference principle” that patterned just outcomes in terms of effects for the least-well-off. ${ }^{43}$ If the meaning was not clear in the original edition of the book, the revised edition in 1975 (which was the basis for translated editions) had the following words added to clarify: "Of course, liberties not on the list, for example, the right to own certain kinds of property (e.g., means of production) and freedom of contract as understood by the doctrine of laissez-faire are not basic; and so they are not protected by the priority of the first principle." 44

As John Tomasi has noted in his important recent work, Rawls's account became influential in part because it was matched off against Robert Nozick's Anarchy, State, and Utopia $^{45}$ released in 1974. Its starker libertarianism — not of widespread appeal at the time,

On these fears, see generally Choudhry, supra note 10 at 24.

Charter, supra note 5, s 7. For a detailed discussion of the development of the language of section 7 , see Strayer, supra note 12 at 256-60.

Reference re Section 94(2) of the Motor Vehicle Act, [1985] 2 SCR 486 at 509.

John Rawls, A Theory of Justice (Cambridge, Mass: Belknap Press, 1971); cf John Tomasi, Free Market Fairness (Princeton: Princeton University Press, 2012) (“[ $t$ ] he publication of A Theory of Justice began a multidecade run of enthusiasm among political philosophers for left liberal and social democratic institutional ideals” at 197).

Rawls, ibid at 61 [emphasis added].

Cf Tomasi, supra note 40 ("Rawls singles out the economic liberties from the other traditional liberal rights and liberties for relegation to a lower level of protection” at 42).

Rawls, supra note 40 at $60,76-80$.

John Rawls, A Theory of Justice, revised ed (Cambridge, Mass: Belknap Press, 1999) at 54. Although the English-language version of the revised text was released only in 1999, as noted in the the preface, ibid at xi, the amendments were made in early 1975 for the preparation of the German edition, with Rawls saying that "[s]ince this revised text includes what I believe are significant improvements, the translated editions (provided accuracy is preserved) until now have been superior to the original.” The revised version thus captures what he had intended all along, even if his circulating English-language version did not reveal all aspects of it until released in 1999.

45 Robert Nozick, Anarchy, State, and Utopia (New York: Basic Books, 1974). 
though it has now arguably become so ${ }^{46}$ — made Rawls appear to be the successor to the classical liberal tradition. ${ }^{47}$

The tradition of liberalism through the 1970s took on Rawlsian characteristics. For example, despite some significant quibbles with the Rawlsian methodology, ${ }^{48}$ Ronald Dworkin nonetheless developed an account of equality with strong salience at least with Rawls' outcomes. ${ }^{49}$ Other writers of the era similarly were attuned to a conception of rights in which economic freedoms did not figure along with other liberal rights, ${ }^{50}$ and the dominant legal-intellectual climate of the time simply did not show the same respect for property rights as had been traditional within Western rights culture. ${ }^{51}$

One immediate conclusion, then, is that the exclusion of property rights had a time-bound quality in terms of the time period in which the matter was discussed. Had the Charter been adopted at a time when property rights were seen as more fundamental, it arguably becomes more conceivable that it would have included property rights.

\section{Political Manoeuvres and Divided Viewpoints}

However, intellectual climates alone do not determine historical events, and we can now add a further element to the story in terms of the simple contingencies of the negotiation process leading up to the text of the Charter. To understand these contingencies, it is necessary to trace a longer narrative of constitutional negotiation, which had been a truly prolonged process in Canada, with literally five decades of debate about an acceptable amending formula in any patriated constitutional text adopted. ${ }^{52}$

The road even to the text of the Charter as adopted in 1982 was not a short one, and Trudeau, perhaps harkening from an older rights tradition, actually did initially propose to

That libertarianism is, for instance, influential within the Tea Party movement, and it is only in recent years that American political life (partly through the influence of Ron Paul) has seen reference to such thinkers as Murray Rothbard. See e.g. Jim Rutenberg \& Serge F Kovaleski, "Paul Disowns Extremists' Views but Doesn't Disavow the Support” The New York Times (25 December 2011), online: <www.ny times.com/2011/12/26/us/politics/ron-paul-disowns-extremists-views-but-doesnt-disavow-thesupport.html>

$47 \quad$ Tomasi, supra note 40 at 46-51.

48 Ronald Dworkin, “The Original Position” (1973) 40:3 U Chicago L Rev 500.

49 See generally Ronald Dworkin, Sovereign Virtue: The Theory and Practice of Equality (Cambridge, Mass: Harvard University Press, 2000). This work embodied prior work, dating to the period in which Rawls was writing and preceding Canadian patriation: Ronald Dworkin, "What is Equality? Part 1: Equality of Welfare” (1981) 10:3 Philosophy \& Public Affairs 185; Ronald Dworkin, "What is Equality? Part 2: Equality of Resources” (1981) 10:4 Philosophy \& Public Affairs 283.

50 Some would draw a sharp distinction between the concepts of "rights" and of "freedoms" and raise concerns of possible conflation when speaking of freedoms amongst a set of rights. However, the Canadian Charter's protection of predominantly negative rights means that there is not necessarily a sharp distinction between freedoms and rights. A freedom is a claim of a sphere of action unregulated by government. A negative right is similarly a claim against restriction by government on some matter, corresponding to a duty of non-interference. Some rights within the Charter do of course impose duties on government other than non-interference. But there is no major distinction pertinent within the Canadian Charter that calls for any overly dogmatic distinction between the two concepts.

51 For a comparison of the Rawlsian tradition to traditional liberalism, see generally Tomasi, supra note 40.

52 For an explanation of the 14 rounds of constitutional negotiation, see James Ross Hurley, Amending Canada's Constitution: History, Processes, Problems and Prospects (Ottawa: Minister of Supply and Services Canada, 1996) at 23-67. 
protect property rights in the Constitution. ${ }^{53}$ What we now recognize as the first draft of the Charter was proffered in 1968 when Trudeau published a substantial consultation paper in the form of a short book, A Canadian Charter of Human Rights. ${ }^{54}$ The proposed Charter would have included property rights: "Using [the Canadian Bill of Rights] as a frame of reference, it is suggested that the rights enumerated ... should be guaranteed: '[g]eneral security of life, liberty and property." 55 Various versions of property rights came under discussion in the period immediately thereafter, including " $[t]$ he right of the individual to life, liberty, security of the person and enjoyment of property, and the right not to be deprived thereof except by due process according to law." 56 These texts met with worries, relating to entrenchment of rights generally, to American judicial decisions, and to worries about clarity of definition of any such right. ${ }^{57}$ In any event, they did not survive into the Victoria Charter, although that instrument itself did not survive. ${ }^{58}$

Property rights continued to be an element of Trudeau's intended constitution. As a means of moving forward, Bill C-60, An Act amending the Constitution was tabled in 1978, and its text specified "the right of the individual to the use and enjoyment of property, and the right not to be deprived thereof except in accordance with law."59 The 1978 Bill, however, was not pursued because some of the proposed amendments relating to the Senate were ultra vires federal jurisdiction, as determined in a reference decision, ${ }^{60}$ but it worked its purpose of spurring debate on the Constitution. ${ }^{61}$ After Bill C-60, property rights persisted into a working draft of the Charter in July 1980, tabled by the federal government following the Quebec referendum in May $1980 .^{62}$

This was classical small-l (and possibly even big-L) liberalism. As has been noted in Johansen, supra note 6 at 1 ,

[t]he entrenchment of property rights in the Constitution appears to have been the policy of the former Liberal government since 1968. In that year, as Minister of Justice, Pierre Trudeau proposed the passage of a charter that would give constitutional protection to certain rights, including the "enjoyment of property.” In 1969, as Prime Minister, Mr. Trudeau again proposed entrenchment of a charter of rights which would have guaranteed the right of an individual to use and enjoy property, with the assurance that there would be no deprivation of property except in accordance with proper legal procedures.

54 The Right Honourable Pierre Elliott Trudeau, A Canadian Charter of Human Rights (Ottawa: Queen's Printer, 1968).

Ibid at 19.

Ibid; Bill of Rights, supra note 4, s 1(a).

See e.g. Constitutional Conference, 3rd Meeting (Ottawa: 8-10 December 1969) at 20-24.

Lorraine Eisenstat Weinrib, “Of Diligence and Dice: Reconstituting Canada’s Constitution” (1992) 42:2 UTLJ 207 at 211, 216.

Constitutional Amendment Bill, supra note 6 at 5.

Re: Authority of Parliament in relation to the Upper House, [1980] 1 SCR 54.

House of Commons Debates, 32nd Parl, 1st Sess, No 22 (29 April 1983) at 25003 [Debates, 29 April 1983].

Meeting of the Continuing Committee of Ministers on the Constitution, Charter of Rights and Freedoms - Discussion Draft, July 4, 1980, Doc 830-81/027 (Montreal: 8-11 July 1980) [Charter Draft, July 1980].

9.(1) Everyone has the right to the use and enjoyment of property, individually or in association with others, and the right not to be deprived thereof except in accordance with law and for reasonable compensation.

(2) Nothing in this section precludes the enactment of or renders invalid laws controlling or restricting the use of property in the public interest or securing against property the payment of taxes or duties or other levies or penalties.

(3) The rights declared by this section may be made subject only to such limitations prescribed by law in addition to those referred to in subsection (2) as are reasonably justifiable in a free and democratic society in the interests of national security or public safety, order, health or morals. 
In all of the above incidents, the property rights protection clauses were fiercely contested by the provinces. Provincial opposition to property rights protection centred mainly around concern about the potential effects property rights would have on their abilities to legislate under the provincial power of property and civil rights. ${ }^{63}$ For example, when the matter went to committee discussion in 1981, Saskatchewan and Quebec had both recently expropriated and nationalized some of their industries ${ }^{64}$ and Prince Edward Island had passed legislation that limited how much land non-residents could own. ${ }^{65}$ Alberta already had property rights protection in its provincial bill of rights, and strongly believed that as a provincial head of power, property rights should be left to be dealt with by the provinces. ${ }^{66}$

Perhaps unsurprisingly, given the sort of legal worries that existed on the part of the provinces, when the federal Liberals released a discussion draft of the Charter on 22 August 1980, in order to address concerns from the provinces, property rights were removed. ${ }^{67}$ The federal government made concessions on the Charter over the summer, but it was still deeply criticized by the Canadian public, so a special joint committee on the Constitution made up of 25 members of Parliament and Senators was established to hear petitions for proposed changes and to debate the Charter's contents. ${ }^{68}$ At the time, there was strong advocacy for the inclusion of property rights by such influential organizations as the Business Council on National Issues and the Canadian Bar Association. ${ }^{69}$ However, the Liberal government was already being accused of forcing the Constitution upon the provinces and therefore the Liberals were not in a strong position to press the provinces to include property right guarantees during the committee negotiations.

The authors focus on the Special Joint Committee hearings of early 1981 as an important moment in patriation history. Some could challenge this approach and might even suggest that only the late 1981 final negotiations meant anything in terms of any final constitutional text. ${ }^{70}$ However, the Joint Committee hearings certainly preconditioned many features of the text. Moreover, the minutes of the hearings represent the most detailed publicly extant record of the thinking behind various features of the text, making them in many ways the source most likely to be used for any constitutional interpretive approaches looking to framers'

Constitution Act, 1867 (UK), 30 \& 31 Vict, c 3, s 92(13), reprinted in RSC 1985, Appendix II, No 5. Alvaro, supra note 8 at 319. The Saskatchewan "nationalization" of the potash industry was technically by a voluntary sale by the companies involved, but it followed on the enactment of legislation under which the province gave itself the power to expropriate the facilities, so the companies involved may not have considered their sale wholly voluntary. Saskatchewan's actions in this instance were complex and are subject to further discussion. We thank Roy Romanow for his perspectives on this point and the next point.

65 Ibid; Canada, Senate and House of Commons, Special Joint Committee on the Constitution of Canada 32nd Parl, 1st Sess, No 45 (26 January 1981) at 36 [Joint Committee 45]. Saskatchewan also had farmland-related legislation against foreign ownership that the province was concerned could have been impacted by some versions of a property rights clause. Alvaro, ibid at 320. Jim McCreedy, “Alta. against federal property guarantee,” Edmonton Journal (26 February 1983) D1. Meeting of the Continuing Committee of Ministers on the Constitution, Federal Draft, August 22, 1980 “The Canadian Charter of Rights and Freedoms,” Doc 830-84/004 (Ottawa: 26-29 August 1980). Sheppard \& Valpy, supra note 10 at 136-37. Canada, Senate and House of Commons, Special Joint Committee on the Constitution of Canada, 32nd Parl, 1st Sess, No 33 (7 January 1981) at 134-35 [Joint Committee 33]. We thank Doug Schmeiser for drawing this perspective to our attention. 
intention or, just generally, for what the drafters were thinking. ${ }^{71}$ Finally, it was during these hearings (and not in late 1981) that property rights were removed for the final time, thus marking them as the moment when the Canadian constitutional text was cast in a form that excluded property rights.

The Special Joint Committee meetings took place in early 1981, several months before the September 1981 release of the Patriation Reference by the Supreme Court of Canada. ${ }^{72}$ The Patriation Reference would decide that unilateral patriation of the Constitution by the federal government, while technically legal, was contrary to constitutional convention. ${ }^{73}$ Even without the Supreme Court ruling, and with Trudeau still claiming to have the right to unilaterally patriate the Constitution, two things were already clear. First, the defence of the unilateral right to patriate was going to be challenged on the basis that the terms of the patriation interfered with provincial jurisdiction, so the federal government would be beginning with some sensitivities to such a point. ${ }^{74}$ Second, even though the Liberals had a majority in the House of Commons, they wanted cross-party support so as not to be seen as enacting a constitution on a one-party basis, and the NDP's support was in turn contingent on provincial approval. ${ }^{75}$

The text of the Charter on property rights may well have been determined over the course of a pivotal weekend. On Thursday, 22 January 1981, the Liberals were presented with an opportunity to include property rights in the Charter as Mr. Crombie, speaking for the Conservatives, put forth an amendment to section 2 that added subsection 2(e), "freedom from unreasonable interference with privacy, family, home, correspondence and enjoyment of property."76 The Conservatives had also previously indicated that they would like to have property rights included within section 7 . The Liberals wanted property rights in the Charter, but thought they would be more appropriate in section 7 than in section $2 .{ }^{77}$ At the time of these proposals Solicitor-General Kaplan was sitting in as the Minister of Justice for Mr. Chrétien, who was in the hospital. Mr. Kaplan told Mr. Crombie that if the Conservatives would withdraw property protection from their proposed amendment to section 2, then the government would agree to support an amendment for the protection of property rights within section 7, on the condition that the Conservatives would be the ones to put forth the motion. ${ }^{78}$ This way, the Liberal party would not appear to be imposing property rights into

$71 \quad$ See generally Adam Dodek, "Where Did (Section) 1 Come From? The Debates Over the Limitations Clause at the Special Joint Committee of the Senate and the House of Commons on the Constitution, 1980-81" (2010) 27 NJCL 77. Dodek argues that the minutes of the Special Joint Committee are effectively the official record of the drafting and discusses, in the context of another part of the Charter, how its text was indeed developed at that Special Joint Committee (ibid at 91). His arguments would support attributing much significance to the Special Joint Committee process.

Re Resolution to amend the Constitution, [1981] 1 SCR 753 [Patriation Reference].

Ibid at 900 .

The provincial reference questions are listed in the opening paragraphs of the Patriation Reference, ibid at 762-65. In all three provinces (Manitoba, Newfoundland, and Quebec), these questions started off with discussion of impacts on provincial jurisdiction. The federal government was aware already by the time of the 1981 Joint Committee meetings that this was a matter over which it was being challenged. Sheppard \& Valpy, supra note 10 at 143.

Canada, Senate and House of Commons, Special Joint Committee on the Constitution of Canada, 32nd Parl, 1st Sess, No 43 (22 January 1981) at 56 [Joint Committee 43].

Ibid at 58 .

Ibid at 59 . 
the Charter against the wishes of the provinces. Mr. Crombie accepted the promise to include property rights within section 7 and withdrew it from his section 2 amendment. ${ }^{79}$

On Friday, 23 January, the amendment was put forth on section 7 as planned. ${ }^{80}$ The amendment added protection of property rights. The proposed property protection was intended to protect property from being taken away without legal means and without a fair hearing. The right would have applied to anyone acting legally in Canada, including corporations. To accomplish this, the section 7 amendment changed the term "fundamental justice" to "natural justice" in order to take advantage of the larger body of law which defined natural justice so as to decrease the uncertainty on how the Courts would interpret the provision. ${ }^{81}$ An NDP amendment which would have applied section 7 to "individuals" instead of "everyone” was rejected. ${ }^{82}$

The proposal seemed close to passing. The Liberal Member of Parliament Mr. Lapierre affirmed that property rights are intrinsic to Canadian society and declared that the government was ready to support the amendment. ${ }^{83}$ However, the NDP Member of Parliament Mr. Robinson objected to the inclusion of property rights in the Charter, arguing that their inclusion would necessarily infringe upon provincial jurisdiction. ${ }^{84} \mathrm{He}$ argued that since the passage of the Constitution package required the consensus of the provinces, property rights should not be included. He also argued that including property rights in the Charter would be the first instance of protection for so-called "economic rights," and if property were to be protected then it would only make sense to include other social and economic rights as well, such as the right to a clean environment. ${ }^{85}$ This argument no doubt traded upon a certain ambiguity in the term "economic rights" — on whose scope there are differing views - but that very ambiguity arguably made it an effective means of running some interference on the proposal that others could then build upon.

Mr. Nystrom, also an NDP Member of Parliament, pointed out that this was the first formal motion for the inclusion of property rights and requested that the Committee delay the vote on the property rights clause in order to have a chance to consult with provincial governments and to consider what other economic rights would be included in the Charter if property rights were going to be included. ${ }^{86}$ His request angered Mr. Lapierre, who said that the possibility of including property rights had been discussed many times and asserted that the NDP, like the Conservatives and the Liberals, had had ample time to consider the issue and the amendment should be voted on immediately. ${ }^{87}$ However, in the end, $\mathrm{Mr}$. Nystrom's request was honoured and the vote was postponed until the following Monday. ${ }^{88}$

\footnotetext{
Ibid.

Canada, Senate and House of Commons, Special Joint Committee on the Constitution of Canada, 32nd Parl, 1st Sess, No 44 (23 January 1981) at 12 [Joint Committee 44].

Ibid.

Ibid at 8 .

Ibid at $15-16$.

Ibid at 17.

Ibid at 19 .

Ibid at 20-21.

Ibid at 24 .

Ibid at 31 .
} 
The pivotal events of that weekend are challenging to unravel. However, they would appear to have impacted upon the text of the Charter that went forward from the Joint Committee. Over the weekend, seemingly on the Sunday, Mr. Broadbent, leader of the NDP, told the government that if they supported the Conservatives' property amendment, then the federal NDP would no longer back the constitutional package. Mr. Broadbent claimed to sympathize with provinces, in particular Saskatchewan, which was the only province with an NDP government at the time, and their fears that protecting property rights might prevent the government from nationalizing industries or from enacting laws regulating ownership of land. ${ }^{89}$

However, Broadbent was not the only actor at work. The Liberal government also received pressure from the government of Saskatchewan that weekend. On Saturday, 24 January, there had been a meeting at the Four Seasons Hotel in Toronto. At the meeting, Attorney-General Roy Romanow of Saskatchewan informed the Liberals that Saskatchewan could not accept a Charter that contained property rights out of concern that property protection would limit Saskatchewan's ability to control foreign or absentee ownership of farmland, and a general desire not to extend the scope of constitutionally protected rights. ${ }^{90}$ Apparently, partly in order to ensure that such a rights protection would not be included in the Charter, Romanow committed Saskatchewan to a bilateral agreement with the federal negotiators whereby Saskatchewan would agree to support the federal constitutional resolution (including acquiescing to the Charter), on condition of including a natural resources clause, property rights being dropped, and Canada obtaining Saskatchewan's consent to any further changes at the Joint Committee. ${ }^{91}$

The threats from the federal and provincial NDP forces might well have been independently sufficient to put to rest the property rights provision. There is no obvious way to say that one of them was paramount over the other. In any case, on Monday, 26 January 1981, the Conservative party put forth their amendment to include property rights in section $7 .^{92}$ In the face of the threats from the NDP to pull support from the Constitutional package, and because of the bilateral deal between the Liberals and Saskatchewan that included a promise to exclude property rights, Mr. Chrétien, who had since resumed his position on the Committee, refused to back the section 7 amendment. ${ }^{93}$

Premier Blakeney of Saskatchewan actually ended up cancelling the bilateral agreement that same afternoon because he realized that agreeing to support Trudeau meant supporting a "moving target." ${ }^{\text {"I }}$ It may be that Blakeney did so after events had already unfolded at the

89 “Drop rights clause or lose backing, Broadbent warns,” The Globe and Mail (26 January 1981) A1.

90 Memorandum from John Whyte to Dwight Newman (30 May 2013) (on file with authors) [Whyte Memo].

91 Ibid. What actually occurred that weekend may well have been more complex. In comments on a draft version of this article, Roy Romanow suggests that he and Howard Leeson actually flew that same weekend from Toronto via San Francisco to Hawaii to consult further with Blakeney without John Whyte having known of this trip. Both Romanow and an emergency meeting of Saskatchewan's Cabinet opposed Blakeney's inclination to do a deal with Trudeau at this stage, with Blakeney then put into a long deliberation on the balcony of the Ilikai Hotel in Hawaii.

Joint Committee 45, supra note 65 at 9.

Ibid at 10.

Whyte Memo, supra note 90. Roy Romanow suggested in comments on this article that this change of view arose from Trudeau failing to call Blakeney at an anticipated time, which apparently later turned out to have been because Trudeau's vehicle had had a flat tire on the road between Montreal and Ottawa. The complex chance events that may have impacted on events illustrate the very contingent nature of the history. 
committee, as Blakeney was at the time in Hawaii, and the time zone difference would appear to have had that implication. ${ }^{95}$ If the Broadbent threat was enough on its own, though, this detail would not be crucial. The change was not on such a contingency as a time zone difference, as there had been enough opposition shown to the section 7 amendment that the Liberals were ready to oppose it and exclude property rights once again.

The Conservatives were furious that the Liberals were no longer willing to support their section 7 amendment. Mr. McGrath reacted in saying:

[T]hat is the most shamefaced betrayal of a parliamentary committee that I have seen here ever, and I can also say this to you, Mr. Minister, that while I am prepared, and my colleagues are prepared to argue with you the substance of our amendment, we are dealing with something much greater than substance here tonight; we are dealing with this government and its inability to keep its word, either to the provinces or to the Parliament or to a Committee of Parliament. ${ }^{96}$

Mr. Chrétien explained that although he was, in principle, in favour of protections for property rights, eventually the Charter would have to be passed in the House of Commons and he could not accept the inclusion of property rights without unanimous support. ${ }^{97}$ Conservative support of the Charter was on the condition that the Charter not be imposed on the provinces, and Saskatchewan MP Nystrom was sided with the Saskatchewan provincial government, who were strongly opposed. Mr. Chrétien appeared to find it frustrating that the Conservatives were pushing for the inclusion of property rights in the Charter when, at the House of Commons, they would vote against it if the provinces were not in support. ${ }^{98}$

In the end, the negotiation process in the context of provincial opposition to a property rights protection had the impact that including the right to property in the Charter meant a risk of losing support for the entire constitutional package. Property rights were sacrificed so the rest of the Charter and the Constitution could move forward, making apparent that property rights had not been central to Trudeau's vision of the Charter even if he would have supported them. As Conservative MP Mr. Epp later put it in 1983, Trudeau bargained property rights for support. ${ }^{99}$

After patriation in 1982, following the late-1981 meetings at which there was no real effort to change the text and put property rights back in, there were nonetheless several further attempts to entrench property rights into the Charter. The first such attempt was in 1983 following a resolution by the British Columbia legislature that section 7 be amended to include the right to enjoyment of property. ${ }^{100}$ British Columbia's premier Mr. Bennett said during the debates, "I remember the shock that many of us felt when the agreement by the Trudeau government to accept the Conservative motion of a Friday night was withdrawn on the Monday because the New Democratic Party in parliament had told the Trudeau

Ibid.

Joint Committee 45, supra note 65 at 11.

Ibid at 34-35.

Ibid.

Debates, 29 April 1983, supra note 61 at 24997.

British Columbia, Legislative Assembly, Official Report of Debates (Hansard), 32nd Parl, 4th Sess (21 September 1982) at 9299. 
government that they would lose their alliance." ${ }^{101}$ The opposition party in turn blamed Bennett for the omission of property rights protection and claimed that "he should have insisted, as the chairman of the Premiers of Canada, that it be retained in the constitution."102

In response to the British Columbia resolution, Trudeau offered to introduce a resolution endorsing the entrenchment of property rights so long as the two opposition parties agreed to pass it after one day of debate. ${ }^{103}$ The Conservatives agreed to this but wanted to make sure it passed before the end of June. The NDP did not immediately respond because of the time limit on the debate. ${ }^{104}$

While the Liberals were waiting on the NDP decision, the Conservative party, in an attempt to force the Liberals to act immediately, proposed the exact same resolution as the Liberals had but in the form of a non-confidence motion. ${ }^{105}$ They had hoped that this would force the Liberals to vote on their own resolution, but instead the non-confidence motion went to a vote and was defeated since the Liberal government obviously could not vote for it. Because of Parliamentary rules which prohibit reintroduction of a defeated resolution in the same session, the manoeuvre halted the discussion on the entrenchment of property rights for the time being. ${ }^{106}$ Here again, one finds some real contingency to the omission of property rights.

Property rights were brought up once again in 1988 with a resolution from the House of Commons that the Constitution Act, 1982 should be amended to recognize "the right to enjoyment of property, and the right not to be deprived thereof, except in accordance with the principles of fundamental justice, and in keeping with the tradition of the usual federalprovincial consultative process."107 The three-year period of endorsement for the resolution expired however and the amendment was never implemented. Property rights remained on constitutional minds during the reform initiatives of the subsequent years. At the time of the negotiation of the Charlottetown Accord following the death of Meech Lake, property rights were similarly raised. However, the ultimate Accord recorded them as one of the areas on which there had been consensus not to proceed as part of that Accord. ${ }^{108}$

There is thus a longer narrative to the exclusion of property rights, with many chance factors along the way. It is conceivable that had some of these factors played out differently, there might have been a different outcome. Arguably, the legal-intellectual culture on property rights made them a tradeable commodity, as it were, facilitating some of the particular negotiation processes that followed. That speaks to a contingency of the time period, in addition to the contingency of the particular negotiation processes. At the same time, a further crucial factor consisted of ongoing assumptions about the effects of a property rights clause, and we turn to this consideration in the next section, where close legal attention to the issue can help to identify some of what went wrong for property rights.

\footnotetext{
$101 \quad$ Ibid at 9301.

$102 \quad$ Ibid at 9302.

$103 \quad$ Debates, 29 April 1983, supra note 61 at 24997.

104 Ibid.

$105 \quad$ Ibid at 24998

$106 \quad$ Ibid at 25002.

107 House of Commons Debates, 33rd Parl, 2nd Sess, No 12 (29 April 1988) at 14989.

108 Consensus Report on the Constitution: Charlottetown, final text (28 August 1992) Part VI.
} 


\section{THREE MistAKEN ASSUMPTIONS IN THE EXCLUSION OF PROPERTY RIGHTS}

Those who opposed property rights outright — some of them on full-fledged ideological grounds, because of favouring social ownership of the means of production - achieved an impact far beyond their numbers in achieving the exclusion of property rights. Their success in altering the classical set of rights into one taking on their preferred ideological position stemmed from contingencies of the process but also from more widespread collaboration by a wider set of actors who were ready to oppose a property rights provision.

The wider set of actors acted on assumptions concerning legal effects of the Charter that we will argue were actually mistaken. In saying as much, we do not seek to be uncharitable to legal advisors and politicians who acted in trying times and on short negotiation schedules. Certain impressions from the legal climate of the time loomed over proceedings in ways that made it difficult to escape certain assumptions. Those drafting the Charter and negotiating on its textual provisions, quite frankly, did not foresee the legal consequences of all of those provisions particularly accurately. ${ }^{109}$ That they did not suggests that they were subject to various kinds of misapprehensions, and we suggest that this was no less true of the property rights context than other Charter contexts.

The wider set of actors, we suggest, acted with three assumptions which proved to be mistaken when considered later in the context of the completed Charter. The mistaken assumptions related to the effects of a property rights provision came from, respectively, (1) the moment in the negotiation process when property rights were lost, (2) mixed discussions about specific text, and (3) assumptions that a property rights clause would have had only further policy-limiting effects rather than altering the interpretation of the Charter in other ways. We will develop each of these in turn.

The exclusion of property rights came about out of significant provincial readiness to oppose a property rights provision, combined with a readiness by Trudeau to trade it away (something he would not have done with other rights provisions). Much provincial opposition to the Charter was rooted in the premiers' concerns for the ongoing role of provincial powers in Canadian federalism, traditional conceptions of parliamentary sovereignty, and a desire to ensure the ability of provinces to engage in policy-making without more constraints than necessary. ${ }^{110}$ Indeed it was argued by some provinces, such as Alberta, that since property and civil rights are under provincial jurisdiction then protection for property rights should be limited to the provincial bills of rights so as not to derogate from provincial powers. ${ }^{111}$ Practically, some provinces worried that the courts' interpretation of property rights could lead to the striking down of provincial laws relating to zoning,

Doug Schmeiser warned of various likely consequences from the text that all tended to be overlooked. For some of his predictions, generally accurate in retrospect and naturally so given how they flow from the text of the Charter, see Douglas A Schmeiser, "The Entrenchment of a Bill of Rights" (1981) 19:3 Alta L Rev 375.

110 Provincial powers were very much at stake within a patriation that is now more commonly associated with the Charter and with the section 35 protection of Aboriginal and treaty rights. To take just one example, the 1982 deal would not have been achieved without the addition of section 92A on natural resource jurisdiction. For discussion on this point, see various passages in Newman, Natural Resource, supra note 34 . 
nationalization of industries, creation of natural parks, and environmental regulation. ${ }^{112}$ These fears were no doubt enhanced by a general climate of concern about a Charter that shifted decision-making on various issues from the general sphere of parliamentary sovereignty to the hands of appointed judges, with premiers as far apart on the ideological spectrum as Alberta Progressive Conservative Premier Peter Lougheed and Saskatchewan Premier Allan Blakeney able to share worries as a result.

However, the first mistake arises from the fact that at the moment in the process when property rights were lost, in early 1981, those concerned with property rights were not fully aware of the final counterbalancing mechanisms within the Charter that existed to protect provincial policy-making. Two important features of the Charter which might have eased the provinces' concerns were the section 1 limitation clause and the section 33 notwithstanding clause. First, in respect of section 1, there were of course limitations envisioned for rights throughout the drafting process of the Charter, but the pertinent clauses varied significantly in form, and it was long unclear what form the test on limits would take. It was during the summer of 1980 that the several federal drafts of that summer began to articulate the limitations clause in a form recognizable as today's section $1 .{ }^{113}$ However, the text of that clause was actually one of the most contentious dimensions before the 1980-81 joint committee throughout its deliberations. ${ }^{114}$ One implication is that those taking views on a property rights clause during those deliberations did not necessarily have a final sense on what the limitations clause would imply for a property rights clause.

Second, the section 33 notwithstanding clause was not even at issue in those hearings and was included only at the end of negotiations with the provinces in late $1981 .{ }^{115}$ If it had been a part of the Charter earlier, it would have served as a potentially decisive answer to an argument that a property rights provision entirely trumped provincial policy-making. The choices of some provinces, for instance, to carry out nationalization of certain industries might have been achieved via the notwithstanding clause. Such a route would arguably, of course, be the honest route that would admit that nationalization without full compensation is a majoritarian choice to act at the expense of the rights of those who have lost their property in the process. With such a clause in the Charter, some of the most overstated worries about the effects of a property rights clause might conceivably have been undermined.

A second mistake arises from the fact that many of the critiques of a property rights provision were carried on in abstract ways, but any actual property rights provision would have consisted of a specific text. Many of the provincial fears could have been addressed by proper construction of the property rights provision. Over the course of the constitutional negotiations, property featured in four different provisions in the various drafts of the Charter. Property rights were included in a standalone section protecting property rights, as part of the mobility rights section, as a fundamental freedom, and as a legal right. Several of these proposed property rights provisions likely would have resulted in different interpretations than were sometimes assumed in a more abstract discussion. 
If property rights had gone forward to the Committee in the draft that went to it, they might have arrived in a more detailed form, with precise text which could have been subject to careful attention. One finds two such possibilities, interestingly enough, in the July 1980 draft. In that draft, property rights were included, first of all, within the mobility rights section. This section read:

8. (2) Every citizen of Canada and every person who has been lawfully admitted to Canada for permanent residence and has not lost the status of a permanent resident has the right

(b) to acquire and hold property in, and to pursue the gaining of livelihood in, any province or territory. $^{116}$

Section 8(2)(b) was particularly troubling for Saskatchewan and Prince Edward Island, both of which had legislation controlling who could own land in their respective provinces, designed to promote local ownership of land and avoid absentee landholding. ${ }^{117}$ Thus, this manner of including property rights in the mobility rights provision gave rise to specific concerns. In part, however, these challenges flowed from the mobility rights provision being at that time in an undetailed form. The ultimate section 6 of the Charter contains very detailed text, ${ }^{118}$ designed to counterbalance various possible concerns that some actors had with various elements of it, ${ }^{119}$ and a detailed approach to the property rights dimension of it might have had more potential than realized to address the concerns of the provinces. Had property rights remained in this text and the text then developed in the sort of detailed ways it ultimately was, solutions might have been found on the specific issues raised and an acceptable arrangement could have been reached.

In the July 1980 draft, property rights were also included as their own separate section:

s.9(1) Everyone has the right to the use and enjoyment of property, individually or in association with others, and the right not to be deprived thereof except in accordance with law and for reasonable compensation.

(2) Nothing in this section precludes the enactment of or renders invalid laws controlling or restricting the use of property in the public interest or securing against property the payment of taxes or duties or other levies or penalties.

(3) The rights declared by this section may be made subject only to such limitations prescribed by law in addition to those referred to in subsection (2) as are reasonably justifiable in a free and democratic society in the interests of national security or public safety, order, health or morals. ${ }^{120}$

There are ample mechanisms to deal with the premiers' concerns within this provision. The phrasing “except in accordance with law and for reasonable compensation” largely suggests procedural due process rather than substantial due process. It suggests that so long

116 Charter Draft, July 1980, supra note 62.

$117 \quad$ Alvaro, supra note 8 at 319.

118 It contains a number of exceptions in a detailed form, leading Régimbald \& Newman, supra note 19, to state at 714 that "[t]his text is more detailed than the text of many Charter provisions."

119 For example, section 6(4) contains an exception for programs ameliorating conditions in disadvantaged provinces. See ibid at 722. 
as there is a valid law authorizing an individual's deprivation of property that deprivation will be authorized. Admittedly, the language concerning “reasonable compensation" would have left some room for substantive review of dimensions of the law, ${ }^{121}$ but even the use of the word "reasonable," rather than terms like those present in the American Hull formula for compensation after expropriation, ${ }^{122}$ shows a textual limitation of the effects of the clause in a manner that might well have responded to many of the premiers' concerns.

Further to that assertion, subsection 2 provides that nothing in section 9 would affect laws enacted for "use of property in the public interest or securing against property the payment of taxes or duties or other levies or penalties.” This gives explicit assurance to the provinces that any law they enact to expropriate property in order to further one of these goals would not be struck down by the judiciary. Subsection 3 affords even further limitations on the right to property in a manner very similar to the current section 1 of the Charter. In short, this provision addresses the concern that the courts would strike down laws which affect property rights because of substantive rather than procedural reasons. Had this detailed text been that put forward in July 1981, when property rights died over the weekend, one might ask if the proponents could have made clearer that they were advocating on the side of what was actually a carefully balanced provision.

Once property rights were up for grabs in the more free-flowing discussions of the Parliamentary Committee, rather than being in the text that the Committee was discussing, a tendency that arose was for parliamentarians seeking property rights to propose an abstract and unnuanced property rights provision. This was natural for those who recognized property rights as being the same in nature as other human rights but meant that the texts they proposed did not answer any of the concerns raised by the provinces. In these abstract formulations, property rights amendments were proposed in two places: in section 2 and in section 7. The section 2 amendment would have added a fifth subsection to the fundamental freedoms: “(e) freedom from unreasonable interference with privacy, family, home, correspondence and enjoyment of property.",123

Inclusion of property rights within the fundamental freedoms might have led to a wider interpretation of what types of action infringe an individual's right to enjoyment of property because of the sentiment that fundamental freedoms should not be taken away or limited unless it is absolutely necessary. ${ }^{124}$ The tendency with interpretation of several of the provisions within section 2 has in fact been to read its provisions as not subject to many internal limits. ${ }^{125}$ If the right to property was conceived of as a fundamental right furthering self-authorship of one's life, like expression and religious freedom, section 2 would have

It bears noting that section 9(1) in the proposed clause, ibid, has a parallelism to the ultimately adopted section 7. The structure of a right to $\mathrm{X}$ and a right not to be deprived of $\mathrm{X}$ except in accordance with $\mathrm{Y}$ has there been interpreted to make the elements of $\mathrm{Y}$ a required element of any rights claim under the section. This was of course debated in Gosselin v Quebec (Attorney General), 2002 SCC 84, [2002] 4 SCR 429.

122 See Bernard J Roth, “NAFTA, Alberta Oil Sands Royalties, and Change: Yes We Can?” (2009) 46:2 Alta L Rev 335 at 339.

$123 \quad$ Joint Committee 43, supra note 76 at 56.

124 Note, though, that the Canadian Charter does not necessarily draw sharp distinctions between rights and freedoms. See supra note 50.

125 For example, this is true of both expression and religion. See Régimbald \& Newman, supra note 19 at 580, 592-93. 
been a very appropriate place for the right on this conception. The provision as drafted did not provide an unlimited protection for property rights however, in that it provided freedom from unreasonable interference with the enjoyment of property, analogous to the ultimate text of section 8 . The wording implies that there will be some judgment call on what constitutes "unreasonable interference," and any interference that is deemed reasonable will be allowed. "Unreasonable interference" is obviously open to interpretation and, in particular, to limitation so as to restrict only particularly egregious kinds of interference. Section 8 has in fact demonstrated through the interpretation of its parallel wording that the courts could actually have developed an interpretation of reasonable and unreasonable intrusions on property rights. ${ }^{126}$ But this future development of interpretation on such provisions was not known at the time, meaning that the imprecision of the language could generate concerns.

The section 7 amendment would have placed property rights within the legal rights category when it was proposed to include the "right to security of the person and enjoyment of property" and the right not to be deprived thereof except in accordance "with the principles of natural justice."127

This differs from the section 2 amendment in that in order for governmental action to deprive a person of property in a constitutional manner, it must do so in accordance with the principles of natural justice as opposed to in a merely reasonable way. In accordance "with the principles of natural justice" is a more precise limitation than "unreasonable interference," and probably would have provided a narrower scope for the right of enjoyment of property. The term "natural justice” is supported by a body of law which clearly defines it as signifying procedural due process. ${ }^{128}$ The use of this term, if it had been continued in section 7, would have provided a degree of certainty in how the courts would interpret the provision.

Indeed, there is an argument to be made that given the level of worry about property rights, had property stayed in section 7 it might have become more likely that the wording would have continued to be based on "natural justice" rather than being changed to "principles of fundamental justice.” An alternative history of the Charter could very easily have emerged. In this alternative history the continuance of classical liberal rights, including property, would have also encouraged the continuance of a more traditional balance in the formulation of the section 7 rights. In turn, this might well have better supported judicial restraint and avoided more generally many of the problems that weighed on the minds of those who removed property rights. Describing such an alternative history, of course, is akin to a certain genre of alternative history novels. But that parallel makes no less real the possibility that a properly drafted section 7 containing property rights might well have avoided many problems that later arose. ${ }^{129}$

See ibid (detailing the gradual development of a more detailed analysis of reasonable expectation of privacy at 653-55).

Joint Committee 44, supra note 80 at 12.

Ibid at $14-15$.

Were we to be writing an alternative history novel of the Charter, we might also pose the possibility that the use of the section 33 override clause might not have carried the same stigma for a government in the context of property rights as compared to other sorts of rights. It might then have had a more publicly acceptable use than it currently does, at least with respect to property rights - and, perhaps with respect to different matters as well, conceivably resulting in a different history of the legislative-judicial balance under the Charter. 
A third mistake was present in the approach of those political actors who supported the idea of property rights in principle but saw its inclusion in the Charter as simply another restriction on the provinces, favouring, for instance, provincial-level protection of property rights. Alberta's attitude was one example, ${ }^{130}$ but the same idea figures in other thinking as well. Those who opposed the Charter generally as an intrusion on parliamentary sovereignty would appear in many cases to have assumed that the second-best option to stopping the Charter generally was to stop as many of its provisions - or at least its seemingly more intrusive provisions — as possible.

However, the mistake here is the failure to recognize that the Charter ultimately became a cohesive instrument, with the courts implicitly using the text of some provisions to help interpret other provisions. It is read holistically, and the courts have generated a set of socalled "Charter values" ${ }^{31}$ as their sense of the general objectives it sought to accomplish, which are then used for various interpretive purposes. ${ }^{132}$

The early Charter jurisprudence, particularly of more activist judges like Chief Justice Brian Dickson and Justice Bertha Wilson, contained statements that wrote of the Charter almost as a Rawlsian instrument, with various descriptions of it as a means of protecting certain basic rights while promoting the welfare of the least-well-off. ${ }^{133}$ And they had a Charter text from which they could construct such a reading. Had the Charter contained the full set of classical rights, including property rights, the holistic reading of the Charter would presumably have been different, or at least ought to have been. On such a revised holistic reading, the presence of the property rights provision could have led to other rights being read differently. The presence of a property rights provision might have, on a holistic reading, affected the reading of other rights in a manner that would have altered their effects on the provinces. The inclusion of a property rights provision would not have spelled a straightforward additional limitation on policy-making but would have helped shape the overall constellation of rights and thus the symbolic and practical meaning of the rights instrument overall.

\section{CONCLUSIONS}

In various ways, the hard bargaining of the negotiation processes contributed to an early exclusion of property rights that made it difficult, then, to reconsider their effects at a later

130 Both leading up to 1982 and the years immediately after, Alberta's position was that property rights were simply within provincial jurisdiction and appropriately protected by the province. See e.g. House of Commons Debates, 32 Parl, 1st Sess, No 22 (29 April 1983) at 25008 quoting Alberta, Legislative Assembly, Hansard, 20th Leg, 1st Sess (19 April 1983) at 622.

131 See e.g. Hill $v$ Church of Scientology of Toronto, [1995] 2 SCR 1130 at para 92.

132 On their role in the development of the common law, as just one example, see RWDSU, Local $558 v$ Pepsi-Cola Canada Beverages (West) Ltd, 2002 SCC 8, [2002] 1 SCR 156.

133 See e.g. Irwin Toy Ltd v Quebec (Attorney General), [1989] 1 SCR 927 ("[t]his Court will not, in the name of minimal impairment, take a restrictive approach to social science evidence and require legislatures to choose the least ambitious means to protect vulnerable groups” at 999, Dickson CJC, Lamer \& Wilson JJ). See also Robert J Sharpe \& Kent Roach, Brian Dickson: A Judge's Journey (Toronto: Osgoode Society for Canadian Legal History, 2003) (emphasizing Dickson's attention to vulnerable groups and his conception of the role of the Supreme Court of Canada when using the Charter to provide a "moral” critique of legislation at 354, 357, 381); Ellen Anderson, Judging Bertha Wilson: Law as Large as Life (Toronto: Osgoode Society for Canadian Legal History, 2001) (describing Justice Wilson's development of a defence of activism that responded to the human situations before the Court at 274-79). 
stage when their effects could have been perceived or shaped more precisely. The intellectual moment at which the Charter was created, the quotidian contingencies of its creation, and the misapprehensions during the process was an interacting set of factors that left property rights out, altering the symbolic and practical effects of the text thereafter.

Some of our claims on the possible different effects of the presence of a property rights clause have, of course, a complex speculative character. Educated speculation is unavoidable but necessary in considering the nature of constitutional might-have-beens. However, taking the different arguments together, we think it entirely plausible to claim that the text and symbolism of a Charter without property rights has led to a different overall interpretation of the Charter compared to a text with property rights.

That fact means, of course, that the introduction of property rights today would either need to be via a carefully defined clause that did not have such effects or that it would potentially work some change to Charter jurisprudence overall. The latter could quite possibly be advocated but with an awareness of possible effects. The fact it was bargained out in the lead-up to 1982 does not give any reason to refrain from discussing it today through further democratic processes.

That may seem to some like a straightforward point. However, often, the text of the Charter is treated as if some sort of inspired text now not to be altered. The point of tracing the contingencies of history on this particular issue is simply to identify the contingency, the historical rootedness, and the time-affected character of the choice made on a particular matter within (or, as it turns out, not within) the Charter. The same would apply to other features of the Charter as well. The text of the Charter is not necessarily fixed for all time, nor should it be.

Debates about the possible amendment of the Charter to include property rights have once again become live, if perhaps in the interesting form of different provinces contemplating the possibility of using the bilateral amending formula to add a province-specific property rights protection. ${ }^{134}$ The merits and demerits of that specific proposal are themselves beyond the scope of this article, and they will no doubt include not only moral theory arguments concerning the role of property rights in individuals being authors of their own lives but also economic arguments concerning the gains to be had from security of property rights. ${ }^{135}$ However, the argument of this article makes clear that there is nothing illegitimate in individuals making those arguments.

Indeed, in some respects, the prevalence of property rights provisions in other constitutional texts and their traditional nature as part of the classical liberal rights order that the Charter otherwise embodies arguably put an onus on those supporting continued exclusion of property rights to justify that exclusion. Part II shows the traditional role of property rights in the classical liberal tradition, and Part IV shows ways in which property rights could potentially be included in the form of nuanced legal text that would avoid many 
of the challenges often put against them. Part III shows that their exclusion arose out of simple political maneuvering. This article, although by its nature not itself leading to any definitive argument for the inclusion of property rights, clears the groundwork for fullfledged argumentation about including property rights and makes clear that those supporting that inclusion should be at no permanent argumentative disadvantage merely from the past exclusion. 